\title{
Comparison of serum maternal adiponectin concentrations in women with isolated intrauterine growth retardation and intrauterine growth retardation concomitant with pre-eclampsia
}

\author{
Barış Büke', Hasan Onur Topçu², Yaprak Engin-Üstün², Nuri Danışman² \\ ${ }^{1}$ Department of Obstetrics and Gynecology, Ege University Faculty of Medicine, Izmir, Turkey \\ ${ }^{2}$ Department of Obstetrics and Gynecology, Zekai Tahir Burak Women's Health Education and Research Hospital, \\ Ankara, Turkey
}

\section{Abstract}

Objective: The aim of this study was to compare serum maternal adiponectin concentrations in pregnant women with isolated intrauterine growth retardation (IUGR) and in pregnant women with IUGR concomitant with pre-eclampsia (IUGRcwPE).

Material and Methods: Thirty patients with isolated IUGR (group 1), 20 patients with IUGRcwPE (group 2), and 30 healthy controls (group 3) between age 18-40 were included into the study. Venous blood samples of those patients were obtained in the starving state. Adiponectin concentrations were measured by enzyme-linked immunosorbent assay in serum obtained after centrifugation. To find the differences between the groups, student t-test and one-way ANOVA statistical methods were used.

Results: There were no differences between the groups in terms of age, body mass index, gestational age, and parity ( $p>0.05$ ). The values of amniotic fluid index $(p<0.001)$ and weight gained during pregnancy $(p=0.017)$ were significantly different when compared among the three groups. The mean concentrations of adiponectin were $94.041 \mathrm{pg} / \mathrm{mL}$ in the IUGR group, $55.717 \mathrm{pg} / \mathrm{mL}$ in the IUGRcwPE group, and $51.831 \mathrm{pg} / \mathrm{mL}$ in the control group. Both of the differences between the IUGR and IUGRcwPE groups ( $p$ value; $<0.05$ ) and IUGR and control groups were statistically significant ( $p$ value; $<0.001$ ). However, there were no significant differences between the IUGRcwPE group and control group ( $p>0.05$ ). Conclusion: We found that IUGR increased maternal serum adiponectin concentrations; however, this rise does not occur in pregnant women with IUGRcwPE. (J Turk Ger Gynecol Assoc 2014; 15: 173-6)

Key words: IUGR, pre-eclampsia, adiponectin

Received: 01 July, 2014

Accepted: 25 July, 2014

\section{Introduction}

Adiponectin, which was first isolated from adipose tissue by Maeda et al. (1) in 1996, has become a mysterious and interesting substance since its first description. It has been thought to inhibit vascular inflammation, improve insulin sensitivity, and have antiatherogenic effects (2).

Some clinical studies showed an association between serum adiponectin concentration and obesity (3-5). A low level of plasma adiponectin concentrations in obese humans and a positive correlation between adiponectin concentrations and insulin sensitivity were shown in another study (6).

Intrauterine growth retardation (IUGR) is described as a fetus whose weight is less than expected based on gestational age and sex, as determined by population standards; frequently chosen cut-off points are below the $10^{\text {th }}$ percentile on these curves (7). Pre-eclampsia refers to the new onset of hypertension and proteinuria after 20 weeks of gestation in a previously normotensive woman (8). Adiponectin receptors are found abundantly in placenta (9). In many studies, maternal serum adiponectin concentrations were constant or decreased during the pregnancy. The unchanged situation of serum adiponectin concentrations were commented on as an independent protective reflex against increased insulin resistance (10-13); however, the decreased adiponectin concentrations were explained by the decreased insulin sensitivity during pregnancy $(14,15)$. A decline in maternal serum adiponectin concentrations in IUGR and reduced plasma adiponectin concentrations were shown in past studies $(16,17)$.

Here, we conducted this present study to compare serum adiponectin concentrations in women with isolated IUGR and in women with IUGR concomitant with pre-eclampsia (IUGRcwPE). 


\section{Material and Methods}

This case-control study was conducted at Zekai Tahir Burak Women's Health Education and Research Hospital in Ankara, Turkey. A total of 80 pregnant women, ages 18 to 40 years, and ones who had more than 28 gestational weeks were enrolled into the study. The pregnant women were classified as having isolated IUGR, IUGRcwPE, and healthy controls. The first group consisted of 30 pregnant women with isolated IUGR, the second group consisted of 20 pregnant women with IUGRcwPE, and the control group consisted of 30 healthy pregnant women. The exclusion criteria were maternal systemic illness, multifetus pregnancies, structural or chromosomal anomalies, and smoking pregnant women. The study was approved by the ethical committee and institutional review board of Zekai Tahir Burak Women's Health Education and Research Hospital, and written informed consent was obtained from each participant. Gestational age (weeks) was assessed by ultrasound examination (Logiq 200 PRO Ultrasound Device; GE Medical Systems, Milwaukee, USA) or according to the last menstrual period, or both. The pregnant women who had estimated fetal weights according to the Hadlock Formula (18) that were below the 10th percentile for gestational age formed the isolated IUGR group. The pregnant women who had IUGR and pre-eclampsia formed the IUGRcwPE group. The pregnant women who had estimated fetal weights according to the Hadlock formula (18) that were at or above the 10th percentile formed the control group. The diagnosis of pre-eclampsia was corrected with the new onset of hypertension and proteinuria after 20 weeks of gestation in a previously normotensive woman.

Fasting blood samples were obtained from the antecubital vein in the third trimester. The samples were centrifuged for 10 minutes at 4000 revolutions per minute and then were stored at $-80^{\circ} \mathrm{C}$. Plasma adiponectin concentrations were measured by using the human adiponectin ACRP30 ELISA kit (EZHADP-61K; Merck Millipore, Massachusetts, USA).

Statistical analysis was performed using Statistical Package for Social Sciences version 14.0 (SPSS; Chicago, IL, USA). The descriptive statistical methods (mean, standard deviation, median) and the comparison of quantitative data were performed using student's t-test and one-way ANOVA. The confidence interval was $95 \%$, and $\mathrm{p}<0.05$ was considered a statistically significant difference among the groups.

\section{Results}

The descriptive characteristics of the women are shown in Table 1. There was no significant difference among the groups in terms of maternal age, gravidity, parity, miscarriage, body mass index (BMI), and gestational age ( $\mathrm{p}>0.05)$.

The median of the ultrasonography measurement of abdominal circumference of the fetuses was $31.6 \pm 3.22$ weeks in the IUGR group, $28.7 \pm 2.92$ weeks in the IUGRcwPE group, and $35.19 \pm 3.3$ weeks in the control group $(\mathrm{p}<0.0001)$. The mean of the amniotic fluid index (AFI) was $52.1 \mathrm{~cm}$ in the IUGR group, $39.3 \mathrm{~cm}$ in the IUGRcwPE group, and $108.6 \mathrm{~cm}$ in the control group. The differences among the groups were statistically significant $(p<0.001)$. The mean of the BMI among the groups was not
Table 1 . The characteristics of the study population

\begin{tabular}{|l|c|c|c|c|}
\hline & \multicolumn{1}{|c|}{$\begin{array}{c}\text { IUGR } \\
\mathbf{n = 3 0}\end{array}$} & $\begin{array}{c}\text { IUGR+PE } \\
\mathbf{n = 2 0}\end{array}$ & $\begin{array}{c}\text { Control } \\
\mathbf{n = 3 0}\end{array}$ & $\begin{array}{c}\mathbf{P} \\
\text { values }\end{array}$ \\
\hline Age (year) & $27.23 \pm 5.981$ & $26.45 \pm 5.196$ & $26.58 \pm 4.726$ & 0.852 \\
\hline Gravidity & $2.20 \pm 1.186$ & $2.16 \pm 1.522$ & $2.04 \pm 1.183$ & 0.892 \\
\hline Parity & $1.03 \pm 1.098$ & $0.84 \pm 1.214$ & $0.69 \pm 0.884$ & 0.487 \\
\hline $\begin{array}{l}\text { Systolic Blood } \\
\text { Pressure } \\
\text { (mm Hg) }\end{array}$ & $112.1 \pm 4.9$ & $156 \pm 13$ & $111.7 \pm 7.3$ & $<0.001$ \\
\hline $\begin{array}{l}\text { Diastolic Blood } \\
\text { Pressure } \\
\text { (mm Hg) }\end{array}$ & $71.21 \pm 2.9$ & $100.4 \pm 8.44$ & $72.5 \pm 5.1$ & $<0.001$ \\
\hline $\begin{array}{l}\text { Proteinuria } \\
\text { (g/day) }\end{array}$ & $37.87 \pm 24.726$ & $2372 \pm 533$ & $33.67 \pm 22.2$ & $<0.001$ \\
\hline BMI (kg/m ${ }^{2}$ ) & $29.0 \pm 1.531$ & $29.573 \pm 3.93$ & $29.133 \pm 2.145$ & 0.731 \\
\hline Miscarriage & $0.23 \pm 0.504$ & $0.28 \pm 0.575$ & $0.31 \pm 0.679$ & 0.893 \\
\hline $\begin{array}{l}* \text { Gestational } \\
\text { age (weeks) }\end{array}$ & $35.743 \pm 3.077$ & $33.895 \pm 1.766$ & $35.269 \pm 3.018$ & 0.710 \\
\hline $\begin{array}{l}\text { bAC } \\
\text { measurement } \\
\text { (weeks) }\end{array}$ & $31.6 \pm 3.22$ & $28.7 \pm 2.92$ & $35.19 \pm 3.3$ & $<0.001$ \\
\hline $\begin{array}{l}\text { Adiponectin } \\
\text { (pg/mL) }\end{array}$ & $94.041 \pm 68.254$ & $55.717 \pm 23.915$ & $51.831 \pm 43.643$ & 0.004 \\
\hline AFI (cm) & $39.3 \pm 18.4$ & $52.1 \pm 24.6$ & $108.6 \pm 53.2$ & $<0.001$ \\
\hline $\begin{array}{l}\text { Weight Gain } \\
\text { (kg) }\end{array}$ & $9.19 \pm 4.53$ & $10.2 \pm 2.6$ & $12.23 \pm 6.34$ & 0.017 \\
\hline $\begin{array}{l}\text { BMI: body mass index; AC: abdominal circumference; AFI: amniotic fluid index; } \\
\text { IUGR: intrauterine growth retardation } \\
\text { *: calculated according to the last menstruation period or first trimester ultraso- } \\
\text { nography } \\
\text { b: the median of the ultrasonography measurement of abdominal circumference, } \\
\text { p<0.05 is significant. } \\
\text { Values are given as mean } \pm \text { SD. }\end{array}$ & & & \\
\hline
\end{tabular}

statistically significant $(\mathrm{p}=0.731)$; however, the weight gain was $9.19 \pm 4.53 \mathrm{~kg}$ in the IUGR group, $10.2 \pm 2.6 \mathrm{~kg}$ in the IUGRcwPE group, and $12.23 \pm 6.34 \mathrm{~kg}$ in the control group. The differences of weight gain between the IUGR and control groups were statistically significant $(p=0.017)$.

The mean concentrations of adiponectin were $94.041 \mathrm{pg} /$ $\mathrm{mL}$ in the IUGR group, $55.717 \mathrm{pg} / \mathrm{mL}$ in the IUGRcwPE group, and $51.831 \mathrm{pg} / \mathrm{mL}$ in the control group (Figure 1). The level of adiponectin concentrations was significantly higher in women with IUGR than in the IUGRcwPE and control groups $(\mathrm{p}<0.05$ and $p<0.001$, respectively). However, there were no significant differences among the IUGRcwPE and control groups ( $>>0.05)$. There was no statistically significant correlation between the serum maternal adiponectin levels and age, BMI, and gestational age (Table 2).

\section{Discussion}

In the current study, we analyzed the prognostic role of maternal serum adiponectin concentrations in IUGR and IUGRcwPE. 


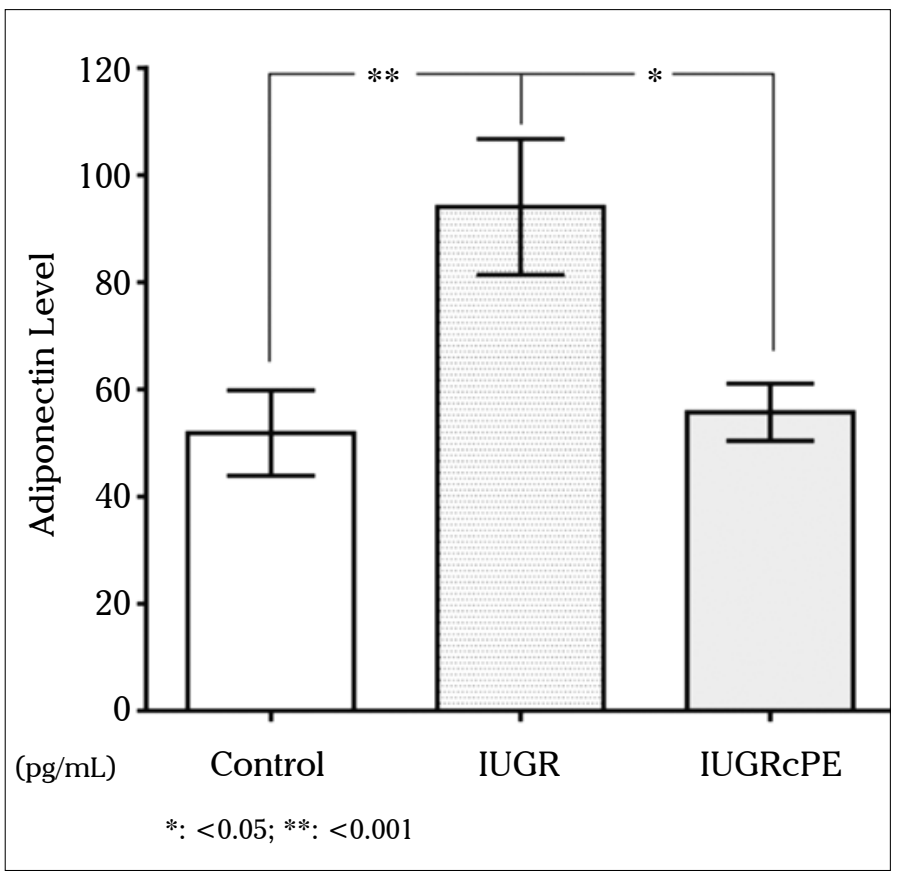

Figure 1. The adiponectin concentrations of the groups

Table 2. Correlation between serum maternal adiponectin levels and clinical parameters

\begin{tabular}{|l|c|c|c|c|c|c|}
\hline \multirow{2}{*}{} & \multicolumn{2}{|c|}{ Age } & \multicolumn{2}{c|}{ BMI } & Gestational Age \\
\cline { 2 - 7 } & $\mathbf{r}$ & $\mathbf{p}$ & $\mathbf{r}$ & $\mathbf{p}$ & $\mathbf{r}$ & $\mathbf{p}$ \\
\hline Adiponectin & -0.104 & 0.713 & 0.072 & 0.799 & 0.342 & 0.728 \\
\hline $\begin{array}{l}\text { R: Pearson correlation coefficient; BMI: body mass index } \\
\text { p<0.05 is significant. }\end{array}$
\end{tabular}

A total of 80 pregnant women were included into the study; of all women, 30 (37.5\%) were in the IUGR group, 20 (25\%) were in the IUGRcwPE group, and $30(37.5 \%)$ were in the control group. We found that adiponectin concentrations were statistically significantly higher in the IUGR group when compared with the IUGRcwPE and control groups.

Adiponectin is a substance that is produced in adipose tissue and released into the bloodstream and has angiogenic, atherosclerotic, insulin-sensitizing, and anti-inflammatory properties (19). In the absence of adiponectin, impaired trophoblastic invasion, endothelial damage, increased insulin resistance, and increased atherosclerosis may present, as seen in pre-eclampsia (19). Contrary to our study, Ramsay et al. (20) showed an increase in adiponectin concentrations in pre-eclamptic women. In two other studies designed by Naruse et al. (19) and Lu et al. (21), adiponectin concentrations were found to be higher in pre-eclamptic pregnant women than normotensive pregnant women. They suggested that endothelial damage may cause elevated adiponectin concentrations. Jarvenpaa et al. (22) studied the adiponectin and adiponectin receptor genes from placental tissue from pre-eclamptic women by polymerase chain reaction (PCR) method and observed a decrease in adiponectin and adiponectin receptor genes and an increase in apoptosis. An association between low adipo- nectin concentrations and pre-eclampsia was shown in another study, and the researchers suggested that low adiponectin concentrations may be a predictive marker of the etiopathogenesis of pre-eclampsia (23). In our study, we found similar serum maternal adiponectin concentrations in the IUGRcwPE and control groups.

Some studies $(24,25)$ reported a positive correlation between IUGR and elevated serum maternal adiponectin concentrations, similar to our study. Fasshauer et al. (26) reported an association between impaired uterine perfusion and increased serum maternal adiponectin concentrations due to endothelial damage. On the other hand, Savvidou et al. (27) reported no association between serum maternal adiponectin concentrations in the middle trimester in women who had IUGR. In a study, adiponectin and leptin concentrations were studied from maternal blood before delivery in umbilical cords in women with IUGR, and it found a decline in adiponectin concentrations and revealed this condition with chronic stress, as in IUGR pathogenesis (16). Street et al. (28) found lower adiponectin concentrations in umbilical cord blood samples in IUGR when compared with a control group and commented that the decline was suppression of adiponectin synthase by chronic inflammation. A recent study by Valdes et al. (29) reported that maternal serum adiponectin concentrations were not useful in predicting subsequent development of IUGR; however, maternal adiponectin concentrations were higher in pregnant women during the first trimester who developed IUGR later. In our study, we found higher maternal adiponectin concentrations in the isolated IUGR group when compared with the IUGRcwPE and control groups.

In conclusion, we detected high maternal serum adiponectin concentrations in isolated IUGR and unchanged adiponectin concentrations in IUGRcwPE. This situation may be explained by the compensatory protective effect of adiponectin in pregnancy with IUGR, and we think that this compensatory mechanism has become insufficient when pre-eclampsia occurs. Further studies that involve more participants are required to understand the role of adiponectin in IUGR and IUGRcwPE.

Ethics Committee Approval: Ethics committee approval was received for this study from the ethics committee of Zekai Tahir Burak Education and Research Hospital.

Informed Consent: Written informed consent was obtained from patients who participated in this study.

Peer-review: Externally peer-reviewed.

Author contributions: Concept - B.B., N.D.; Design - B.B., H.O.T.; Supervision - Y.E-Ü., N.D.; Resource - B.B., H.O.T.; Materials - B.B., H.O.T.; Data Collection\&/or Processing - B.B., H.O.T.; Analysis\&/or Interpretation - B.B., H.O.T., Y.E-Ü. ; Literature Search - B.B., H.O.T., Y.E-Ü.; Writing - H.O.T, B.B.; Critical Reviews - Y.E-Ü., N.D.

Conflict of Interest: No conflict of interest was declared by the authors.

Financial Disclosure: The authors declared that this study has received no financial support. 


\section{References}

1. Maeda K, Okubo K, Shimomura I, Funahashi T, Matsuzawa Y, Matsubara K. cDNA cloning and expression of a novel adipose specific collagen-like factor, apM1 (AdiPose Most abundant Gene transcript 1). Biochem Biophys Res Commun 1996; 221: 286-9. [CrossRef]

2. Ouchi N, Kihara S, Arita Y, Maeda K, Kuriyama H, Okamoto Y, et al. Novel modulator for endothelial adhesion molecules: adipocytederived plasma protein adiponectin. Circulation 1999; 100: 2473-6. [CrossRef]

3. Arita Y, Kihara S, Ouchi N, Maeda K, Kuriyama H, Okamoto Y, et al. Adipocyte-derived plasma protein adiponectin acts as a plateletderived growth factor-BB-binding protein and regulates growth factor-induced common postreceptor signal in vascular smooth muscle cell. Circulation 2002; 105: 2893-8. [CrossRef]

4. Hotta K, Funahashi T, Bodkin NL, Ortmeyer HK, Arita Y, Hansen BC, Matsuzawa Y. Circulating concentrations of the adipocyte protein adiponectin are decreased in parallel with reduced insulin sensitivity during the progression to type 2 diabetes in rhesus monkeys. Diabetes 2001; 50: 1126-33. [CrossRef]

5. Yang WS, Lee WJ, Funahashi T, Tanaka S, Matsuzawa Y, Chao CL, et al. Weight reduction increases plasma levels of an adiposederived anti-inflammatory protein, adiponectin. J Clin Endocrinol Metab 2001; 86: 3815-9. [CrossRef]

6. Yamauchi T, Kamon J, Waki H, Terauchi Y, Kubota N, Hara K, et al. The fat-derived hormone adiponectin reverses insulin resistance associated with both lipoatrophy and obesity. Nat Med 2001; 7: 941-6. [CrossRef]

7. Anonymous. Intrauterine growth retardation. Clinical Management Guidelines for Obstetrician-Gynecologists. ACOG Pract Bull 2000: $1-11$.

8. Sibai BM, Caritis S, Hauth J, National Institute of Child H, Human Development Maternal-Fetal Medicine Units N. What we have learned about preeclampsia. Semin Perinatol 2003; 27: 239-46. [CrossRef]

9. Chen J, Tan B, Karteris E, Zervou S, Digby J, Hillhouse EW, et al. Secretion of adiponectin by human placenta: differential modulation of adiponectin and its receptors by cytokines. Diabetologia 2006; 49: 1292-302. [CrossRef]

10. Cortelazzi D, Corbetta S, Ronzoni S, Pelle F, Marconi A, Cozzi V, et al. Maternal and foetal resistin and adiponectin concentrations in normal and complicated pregnancies. Clin Endocrinol (Oxf) 2007; 66: 447-53. [CrossRef]

11. Mazaki-Tovi S, Kanety H, Pariente C, Hemi R, Wiser A, Schiff E, et al. Maternal serum adiponectin levels during human pregnancy. J Perinatol 2007; 27: 77-81. [CrossRef]

12. Mastorakos G, Valsamakis G, Papatheodorou DC, Barlas I, Margeli $\mathrm{A}$, Boutsiadis $\mathrm{A}$, et al. The role of adipocytokines in insulin resistance in normal pregnancy: visfatin concentrations in early pregnancy predict insulin sensitivity. Clin Chem 2007; 53: 1477-83. [CrossRef]

13. Soylemez N, Demirbag R, Sezen Y, Yildiz A, Akpinar O. [The levels of the leptin and adiponectin according to body mass index and their relationship with oxidative parameters]. Anadolu Kardiyol Derg 2010; 10: 391-6. [CrossRef]

14. O'Sullivan AJ, Kriketos AD, Martin A, Brown MA. Serum adiponectin levels in normal and hypertensive pregnancy. Hypertens Pregnancy 2006; 25: 193-203. [CrossRef]
15. Catalano PM, Hoegh M, Minium J, Huston-Presley L, Bernard S, Kalhan S, et al. Adiponectin in human pregnancy: Implications for regulation of glucose and lipid metabolism. Diabetologia 2006; 49: 1677-85. [CrossRef]

16. Kyriakakou M, Malamitsi-Puchner A, Militsi H, Boutsikou T, Margeli A, Hassiakos D, et al. Leptin and adiponectin concentrations in intrauterine growth restricted and appropriate for gestational age fetuses, neonates, and their mothers. Eur J Endocrinol 2008; 158: 343-8. [CrossRef]

17. Ouyang $\mathrm{Y}$, Chen $\mathrm{H}$, Chen $\mathrm{H}$. Reduced plasma adiponectin and elevated leptin in pre-eclampsia. Int J Gynaecol Obstet 2007; 98: 110-4. [CrossRef]

18. Hadlock FP, Harrist RB, Sharman RS, Deter RL, Park SK. Estimation of fetal weight with the use of head, body, and femur measurements--a prospective study. Am J Obstet Gynecol 1985; 151: 333-7. [CrossRef]

19. Naruse K, Yamasaki M, Umekage H, Sado T, Sakamoto Y, Morikawa $\mathrm{H}$. Peripheral blood concentrations of adiponectin, an adipocytespecific plasma protein, in normal pregnancy and preeclampsia. $\mathrm{J}$ Reprod Immunol 2005; 65: 65-75. [CrossRef]

20. Ramsay JE, Jamieson N, Greer IA, Sattar N. Paradoxical elevation in adiponectin concentrations in women with preeclampsia. Hypertension 2003; 42: 891-4. [CrossRef]

21. Lu D, Yang $X$, Wu $Y$, Wang $H$, Huang $H$, Dong M. Serum adiponectin, leptin and soluble leptin receptor in pre-eclampsia. Int $\mathrm{J}$ Gynaecol Obstet 2006; 95: 121-6. [CrossRef]

22. Jarvenpaa J, Vuoristo JT, Santaniemi M, Ukkola O, Savolainen ER, Jaaskelainen M, et al. Adiponectin induced placental cell apoptosis could be mediated via the ADIPOR1-receptor in pre-eclampsia with IUGR. J Perinat Med 2009; 37: 257-62. [CrossRef]

23. D'Anna R, Baviera G, Corrado F, Giordano D, Di Benedetto A, Jasonni VM. Plasma adiponectin concentration in early pregnancy and subsequent risk of hypertensive disorders. Obstet Gynecol 2005; 106: 340-4. [CrossRef]

24. Evagelidou EN, Giapros VI, Challa AS, Kiortsis DN, Tsatsoulis AA, Andronikou SK. Serum adiponectin levels, insulin resistance, and lipid profile in children born small for gestational age are affected by the severity of growth retardation at birth. Eur J Endocrinol 2007; 156: 271-7. [CrossRef]

25. Suliman SG, Stanik J, McCulloch LJ, Wilson N, Edghill EL, Misovicova N, et al. Severe insulin resistance and intrauterine growth deficiency associated with haploinsufficiency for INSR and CHN2: new insights into synergistic pathways involved in growth and metabolism. Diabetes 2009; 58: 2954-61. [CrossRef]

26. Fasshauer M, Bluher M, Stumvoll M, Tonessen P, Faber R, Stepan H. Differential regulation of visfatin and adiponectin in pregnancies with normal and abnormal placental function. Clin Endocrinol (Oxf) 2007; 66: 434-9. [CrossRef]

27. Savvidou MD, Sotiriadis A, Kaihura C, Nicolaides KH, Sattar N. Circulating levels of adiponectin and leptin at 23-25 weeks of pregnancy in women with impaired placentation and in those with established fetal growth restriction. Clin Sci (Lond) 2008; 115: 219-24. [CrossRef]

28. Street ME, Volta C, Ziveri MA, Viani I, Bernasconi S. Markers of insulin sensitivity in placentas and cord serum of intrauterine growth-restricted newborns. Clin Endocrinol (Oxf) 2009; 71: 394-9. [CrossRef]

29. Valdes ER, Lattes KA, Munoz HS, Barja PY, Papapietro KV. Firsttrimester adiponectin and subsequent development of preeclampsia or fetal growth restriction. Gynecol Obstet Invest 2011; 72: 152-6. [CrossRef] 